\title{
INVENTARISASI EMISI SUMBER BERGERAK DI JALAN (ON ROAD) KOTA DENPASAR
}

\author{
Christine Prita Purwanto ${ }^{1 *}$, I Wayan Arthana ${ }^{1}$, I Wayan Suarna ${ }^{1}$ \\ ${ }^{1}$ Program Studi Magister Ilmu Lingkungan Universitas Udayana Bali \\ *Email : christineprita@gmail.com
}

\begin{abstract}
The growth of population in Denpasar City followed by increasing of transportation facilities that potentially cause pollution by vehicle emissions and cause serious environmental problems and which has adverse effect to the human health. The research aimed to estimate the number and distribution of emission gases on air pollutants, such as: $\mathrm{PM}_{10}, \mathrm{NO}_{x}, \mathrm{SO}_{2}, \mathrm{CO}, \mathrm{CO}_{2}$ and $\mathrm{HC}$. The calculation of estimated based on road mobile sources (On Road) in Denpasar City, includes all known sources such as the highway, small roads, terminals, and parking lots. The calculation of emissions is calculated by using the approach of emission estimation method.

The total load of emissions by moving source on the street in Denpasar for each pollutant gases are: value of $\mathrm{NO}_{\mathrm{x}}$ is 3765.89 tons/year, value of $\mathrm{SO}_{2}$ is 212.34 tons/year, value of $\mathrm{HC}$ is 20049.87 tons/year, value of $\mathrm{PM}_{10}$ is 444.16 tons/year, value of $\mathrm{CO}_{2}$ is $984,280.21$ tons/ year, and value of $\mathrm{CO}$ is 55432.04 tons/year. Overall, the total load of pollutant emissions gases of Denpasar City is greater than the total load of pollutant emissions gases in Palembang city. Spatially, the distribution of pollutant gas emissions are not spread evenly. The pollutants emissions of $\mathrm{NO}_{\mathrm{x}}, \mathrm{CO}_{2}$, and $\mathrm{HC}$ for each gases have the highest values are about 115 - 239 tons/year, $26.944-4.735$ tons/year, and $471-954$ tons/year distributed at West Denpasar District and Niti Mandala Renon area. The highest pollutans emission of $\mathrm{SO}_{2}$ is about 15,5-44 tons/year, distributed at West Denpasar District. The highest pollutans emission of $\mathrm{PM}_{10}$ is about 11,5-21 tons/year, distributed at West Denpasar District, Badung Market area, Puputan Square area, and Niti Mandala Renon area. The highest CO pollutant emission is about 1277-1912 tons/year, distributed at West Denpasar District, Badung Market area, Puputan Square area, Niti Mandala Renon area, and Udayana University area.
\end{abstract}

Keywords: Vehicle Emissions; Emissions Inventory; Air Pollution; Transportation; Denpasar City.

\section{PENDAHULUAN}

Laju pertumbuhan Kota Denpasar cukup yang padat ditandai dengan pembangunan fisik kota, berdirinya pusat-pusat perdagangan dan jasa serta diikuti melonjaknya jumlah populasi kendaraan bermotor. Pada tahun 2010, kepadatanpenduduk di Kota Denpasar telah mencapai 6.171 jiwa $/ \mathrm{km}^{2}$. Angka ini merupakan angka tertinggi di propinsi Bali. Kepadatan penduduk yang semakin meningkat akan menambah jumlah transportasi di wilayah Kota Denpasar, hal ini tentu mempengaruhi kualitas udara Kota Denpasar. Bila dilihat dari sumber pencemarnya, maka pencemaran udara sumber bergerak sebagianbesar bersumber dari kendaraan bermotor. Jumlah kendaraan bermotor dari tahun ke tahunjumlahnya terus meningkat dimana pada tahun 2003 jumlah kendaraan bermotor di KotaDenpasar berjumlah 345.332 unit terus mengalami peningkatan dari tahun ke tahun, sampai tahun 2007 sebesar 481.086 unit dengan kenaikan rata-rata sebesar $7 \%$ tiaptahunnya. Hal ini mengakibatkan peningkatan kepadatan lalu lintas dan hasil buangan emisi yang merupakan salah satu sumber pencemaran udara sekaligus berpotensi menimbulkan masalah lingkungan yang serius dan juga berdampak pada kesehatan.

Berdasarkan Peraturan Pemerintah No. 41 tahun 1999 pasal 6 ayat 4 dan juga berdasarkan komitmen pemerintah Indonesia pada pertemuan G20 di Pittsburgh - USA pada 25 September 2009 untuk mengurangi tingkat emisi GRK sebesar 26\% di tahun 2020, maka diperlukan kegiatan inventarisasi sumber pencemar udara atau yang disebut dengan inventarisasi emisi (IE) sebagai salah satu langkah awal dalam menangani permasalahan kualitas udara. Kota Denpasar ikut melakukan kegiatan inventarisasi emisi guna menunjang kebijakan Nasional, melalui IE dapatdiidentifikasi sumber-sumber pencemar udara dan juga dapat diperkirakan jumlah spesifik pencemar udara yang diemisikan dalam periode waktu tertentu. Melalui inventarisasi emisi dapat diidentifikasi jenis pencemar udara berdasarkan sumbernya, sehingga rencana aksi yang disusun juga bisa sesuai dengan target beban emisi dari sumber mana yang akan diturunkan. Berdasarkan permasalahan diatas, maka dilakukan penelitian untuk menghitung beban emisi pencemar udara dan sebaran emisibeban emisi gas-gas pencemar udara, yang meliputi: $\left(\mathrm{PM}_{10}\right)$, 
$\left(\mathrm{NO}_{\mathrm{x}}\right),\left(\mathrm{SO}_{2}\right),(\mathrm{CO}),\left(\mathrm{CO}_{2}\right)$ dan $(\mathrm{HC})$ dari sumber bergerak di jalan (On Road) Kota Denpasar.

\section{METODOLOGI}

Untuk keperluan analisis emisi, Kota Denpasar yang memiliki luas $127,78 \mathrm{~km}^{2}$ mempergunakan grid $1 \mathrm{x} 1 \mathrm{~km}$ sehingga terbentuk 165 grid, seperti terlihat pada Gambar 1.

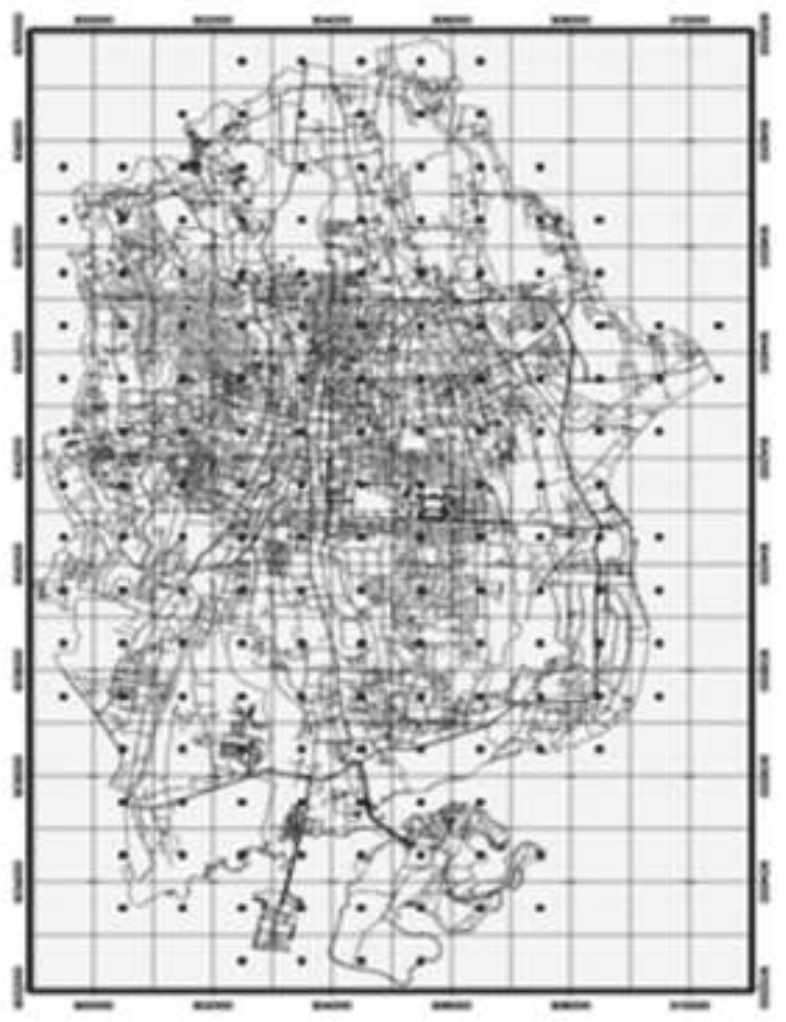

Gambar 1. Pembagian grid Kota Denpasar data primer dan data sekunder.Data primer didapatkan melalui kuisioner dan survei lapangan. Data primer yangdikumpulkan meliputi: Data jarak tempuh dan waktu perjalanan tiap jenis kendaraan (sepeda motor, kendaraan ringan, bus, kendaraan berat, dan kendaraan tidak bermotor) di wilayah Denpasar; dataperjalanan jenis kendaraan mikrolet (jarak trayek dan waktu tempuh); datakomposisi penggunaan bahan bakar di SPBU.

Data sekunder didapatkan melalui kajian kepustakaan Selain itu, survei instansi dilakukan untuk memperoleh data dari instansi yang terkait dengan temapenelitian. Setelah setiap data terkumpul,tabulasi dan analisis data serta perhitungan emisi awal dilakukan. Perhitungan emisi dilakukan dengan menggunakanpendekatan beban emisi sebagai berikut:

Beban Emisi = Jumlah kendaraan (kendaraan (ton/tahun) hari) $\times$ Jarak tempuh $(\mathrm{km}) \times$ faktor emisi ( $\mathrm{g} / \mathrm{km} /$ kendaraan) $\mathrm{x}$ $10^{-6}(\mathrm{ton} / \mathrm{g}) \times 365$ (hari/th)

\section{HASIL}

\subsection{Beban Emisi Sumber Bergerak di Jalan (On Road)}

Total emisi tiap kendaran pada masing-masing ruas jalan raya di Kota Denpasar berdasarkan perhitungan beban emisi menggunakan Mobilev, seperti terlihat pada Tabel 1.

Perhitungan juga dilakukan pula terhadap beban emisi ruas jalan kecil di Kota Denpasar dengan menggunakan nilai VKT (Vehicle Kilometer Travel) Mobilev, data Samsat, nilai odometer, dan nilai ekonomi bahan bakar kendaraan bermotor nasional

Tabel 1. Total emisi tiap jenis kendaraan pada ruas jalan raya

\begin{tabular}{lcccrrr}
\hline Jenis Kendaraan & $\mathrm{NOx}$ (ton/thn) & $\mathrm{SO}_{2}$ (Ton/Thn) & $\mathrm{HC}$ (ton/thn) & $\mathrm{PM}_{10}$ (Ton/Thn) & $\mathrm{CO}_{2}$ (ton/thn) & $\mathrm{CO}_{\text {(ton/thn) }}$ \\
\hline LDV & $2.652,61$ & 137,22 & $2.645,09$ & 319,20 & $606.234,79$ & $24.579,78$ \\
buses & 122,14 & 7,40 & 9,26 & 2,36 & $10.758,95$ & 18,09 \\
Scooters & 346,27 & 31,77 & $16.851,14$ & 104,93 & $291.908,87$ & $29.834,83$ \\
HDV & 582,18 & 31,95 & 53,37 & 10,65 & $59.113,62$ & 83,28 \\
TOTAL & $3.703,20$ & 208,34 & $19.558,86$ & 437,14 & $968.016,23$ & $54.515,98$ \\
\hline
\end{tabular}

LDV (Light Duty Vehicle) = Kendaraan bermotor beroda empat termasuk kendaraan penumpang, opelet, angkot, pick-up.

Buses atau Bis = Semua jenis kendaraan penumpang yang daya angkutnya lebih besar dari 12 orang.

Scooter atau sepeda motor $=$ Kendaraan bermotor dengan dua atau tiga roda .

HDV $($ Heavy Duty Vehicle $)=$ Kendaraan bermotor dengan roda lebih dari empat.

Penelitian dan pengolahan data dilakukan di Pusat Penelitian Lingkungan Hidup, Udayana. Penelitian dilakukan pada bulan Februari 2014 sampai dengan April 2014.Adapun sumber data yang digunakan dalam penelitian ini dibagi atas dua, yaitu dalam Peraturan Menteri Lingkungan Hidup No. 12/ 2010. Berdasarkan hasil analisis, nilai VKT ruas jalan kecil bernilai 1,68\% dari total luas cakupan VKT area Mobilev ruas jalan raya. 
Tabel 2. Total beban emisi ruas jalan kecil di Kota Denpasar dari sumber bergerak on-road

\begin{tabular}{lrrrrrr}
\hline & \multicolumn{7}{c}{ Total Beban Emisi (Ton/Thn) } \\
\cline { 2 - 7 } Total VKT Area & \multicolumn{1}{c}{ NOx } & \multicolumn{1}{c}{ SO $_{2}$} & HC & PM $_{10}$ & C O & CO $_{2}$ \\
\hline Jalan Raya Mobilev & $3.703,20$ & 208,34 & $19.558,86$ & 437,14 & $968.016,23$ & $54.515,98$ \\
Jalan Kecil & 62,21 & 3,50 & 328,59 & 7,34 & $16.262,67$ & 915,87 \\
\hline
\end{tabular}

Tabel 3 Total beban emisi di Kota Denpasar dari Sumber Terminal

\begin{tabular}{lcccccc}
\hline & \multicolumn{5}{c}{ Total Beban Emisi (Ton/Thn) } \\
\cline { 2 - 7 } Terminal & NOx & $\mathbf{S O}_{2}$ & HC & $\mathbf{P M}_{10}$ & $\mathbf{C O}$ & $\mathbf{C O}_{2}$ \\
Terminal Ubung & 0,5794 & 0,0005 & 0,0349 & 0,0165 & 0,2800 & 0,0660 \\
Terminal Barang & 0,1013 & 0,0006 & 0,0058 & 0,0029 & 0,3000 & 0,0660 \\
Terminal Kreneng & 0,0032 & 0,0001 & 0,0035 & 0,0000 & 0,4000 & 0,0660 \\
Terminal Tegal & 0,0038 & 0,0001 & 0,0004 & 0,0004 & 0,0024 & 0,0660 \\
TOTAL & $\mathbf{0 , 6 8 7 7}$ & $\mathbf{0 , 0 0 1 3}$ & $\mathbf{0 , 0 4 4 6}$ & $\mathbf{0 , 0 1 9 7}$ & $\mathbf{0 , 9 8 2 4}$ & $\mathbf{0 , 2 6 4 1}$ \\
\hline
\end{tabular}

Tabel 4. Total beban emisi di Kota Denpasar dari tempat parkir

\begin{tabular}{lcrrrr}
\hline \multirow{2}{*}{ Jenis Parkir } & \multicolumn{2}{c}{ Rataan Kendaraan Parkir/Thn } & \multicolumn{2}{c}{ Faktor Emisi } & \multirow{2}{*}{ Total HC (Ton/Thn) } \\
\cline { 2 - 4 } & Motor & Mobil & Motor & Mobil & \\
\hline Parkir area & 19.711 .460 & 4.132 .165 & 7,5 & 14,6 & 208,17 \\
Parkir di jalan & 1.899 .095 & 605.170 & 7,5 & 14,6 & 23,08 \\
& & & Total Emisi HC & & 231,25 \\
\hline
\end{tabular}

Tabel 5. Total Beban Emisi untuk Masing-masing Jenis Aktivitas Kendaraan

\begin{tabular}{lrrrrrr}
\hline & \multicolumn{7}{c}{ Total Beban Emisi (Ton/Thn) } \\
\cline { 2 - 7 } Jenis Kendaraan & NOx & $\mathbf{S O}_{2}$ & HC & PM $_{10}$ & $\mathbf{C O}_{2}$ & $\mathbf{C O}$ \\
\hline Jalan Raya & $3.703,20$ & 208,34 & $19.558,86$ & 437,14 & $968.016,23$ & $54.515,98$ \\
Jalan Kecil & 62,00 & 4,00 & 329,00 & 7,00 & $16.263,00$ & 916,00 \\
Terminal & 0,69 & 0,00 & 0,04 & 0,02 & 0,98 & 0,06 \\
Parkir & 0,00 & 0,00 & 162,00 & 0,00 & 0,00 & 0,00 \\
TOTAL & $3.765,89$ & 212,34 & $20.049,87$ & $\mathbf{4 4 4 , 1 6}$ & $\mathbf{9 8 4 . 2 8 0 , 2 1}$ & $\mathbf{5 5 . 4 3 2 , 0 4}$ \\
\hline
\end{tabular}

Terminal merupakan salah satu yang menghasilkan sumber emisi dari sumber bergerak on-road. Hal ini dikarenakan terminal merupakan bagian dari utiliti transportasi yang melibatkan sumber-sumber emisi dari sumber emisi bergerak on-road. Berdasarkan data dari Dinas Perhubungan Kota Denpasar, di Kota Denpasar terdapat 4 terminal, yaitu Terminal Tegal, Terminal Kreneng, Terminal Ubung dan Terminal Barang. Tabel 3 menyajikan total beban emisi di Kota Denpasar dari sumber terminal.

Selain terminal, tempat parkir juga merupakan salah satu area yang menghasilkan emisi dari sumber bergerak on-road. Survei tempat parkir dibagi menjadi 2 tempat, yakni: parkir dalam area dan parkir pinggir jalan, seperti yang terlihat pada Tabel 4.
Berdasarkan hasil perhitungan pada tabel 1, 2, 3 dan 4, maka dapat dihitung total beban emisi gas polutan $\mathrm{NO}_{\mathrm{x}}, \mathrm{SO}_{2}, \mathrm{HC}, \mathrm{PM}, \mathrm{CO}_{2}$ dan $\mathrm{CO}$ dari empatjenis aktivitas kendaraan yang telah dijumlahkan yang terdiri dari Jalan Raya, Jalan Kecil, Terminal dan Parkir seperti pada Tabel 5.

\subsection{Distribusi Sebaran Beban Emisi Polutan $\mathrm{NO}_{\mathrm{x}}, \mathrm{SO}_{2}, \mathrm{HC}, \mathrm{PM}_{10}, \mathrm{CO}_{2}$, dan $\mathrm{CO}$ dari Sumber Bergerak (On Road) Kota Denpasar \\ Distribusi sebaran emisi polutan $\mathrm{NO}_{\mathrm{x}}, \mathrm{SO}_{2}, \mathrm{HC}$, $\mathrm{PM}_{10}, \mathrm{CO}_{2}$, dan COdarisumber bergerak (on road)} yang dihitung dari total emisi berbagai jenis kegiatan lalu lintas kendaraan baik di jalan raya, jalan kecil, terminal maupun dilapangan parkir, seperti terlihat pada Gambar 2. 


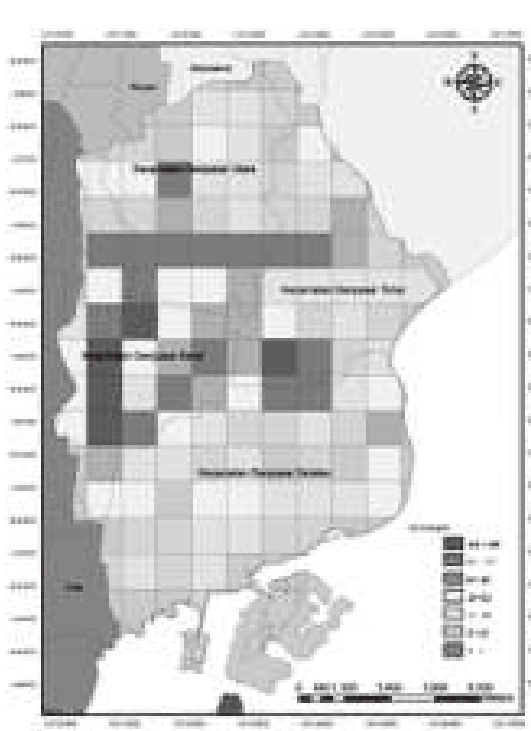

(a)

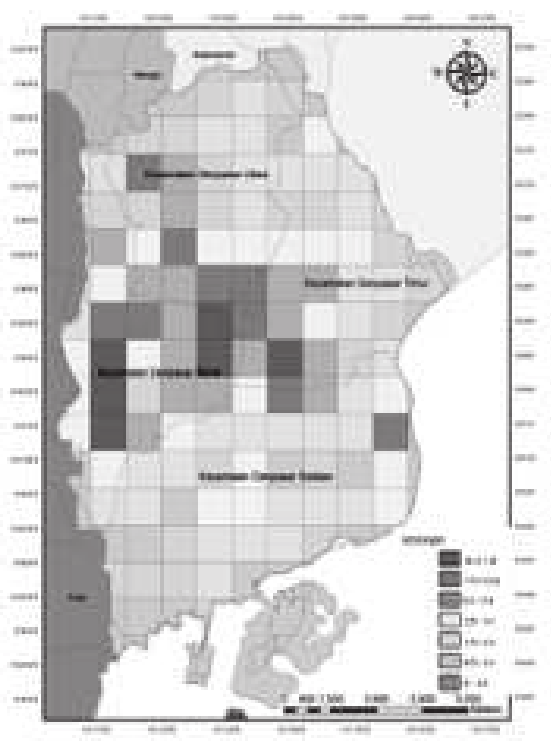

(d)

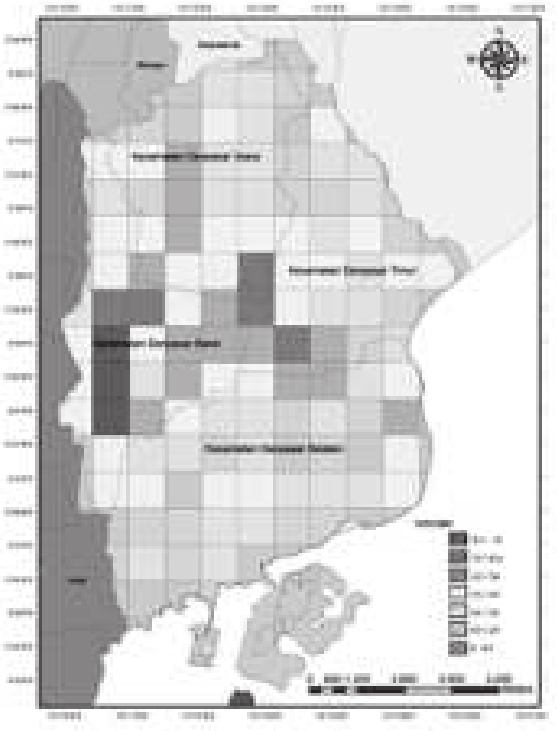

(b)

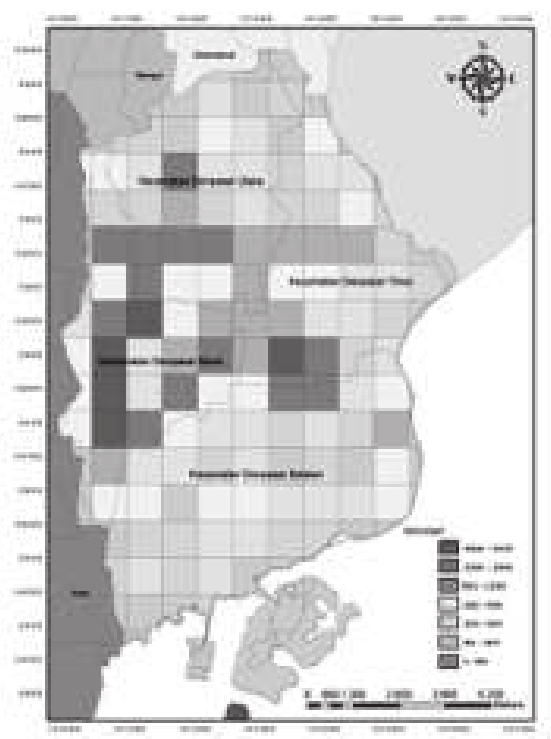

(e)

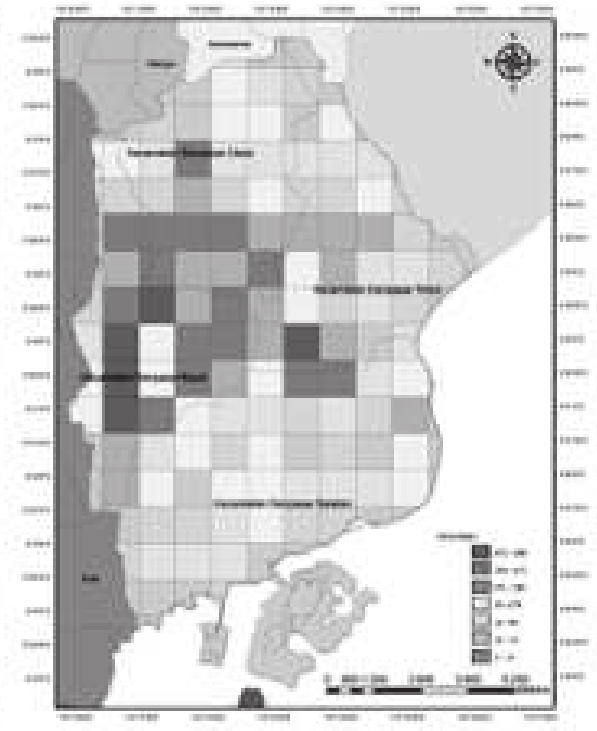

(c)

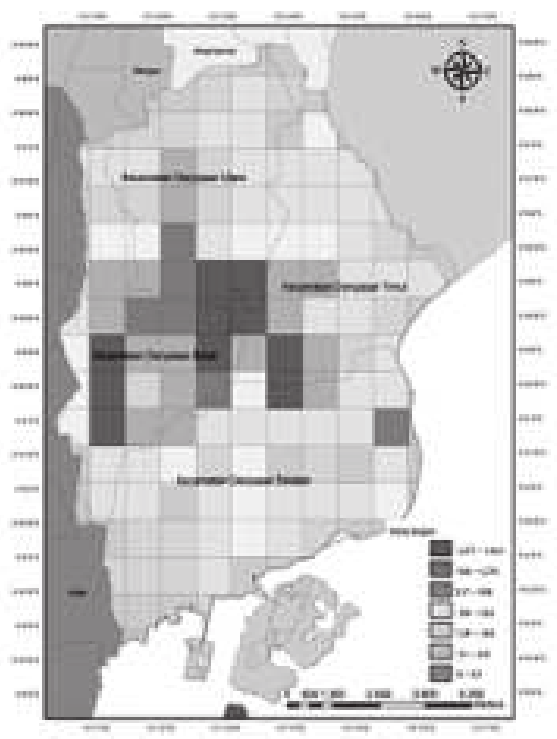

(f)

Gambar 2.

Distribusi spasial sumber emisi polutan: a.NO $\mathrm{NO}_{\mathrm{x}}$ b.SO; ; $\mathrm{HC}$; d. $\mathrm{PM}_{10}$; e. $\mathrm{CO}_{2}$; dan f. $\mathrm{CO}$

\section{PEMBAHASAN}

\subsection{Beban Emisi Sumber Bergerak Gas Polutan NO di Kota Denpasar}

Berdasarkan Tabel 1 dan Tabel 5, besarnya nilai polutan NOx mencapai total 3.765,89 ton/tahun dan tingginya nilai estimasi emisi NOx ini sebagian besar berasal dari emisi jalan-jalan raya dan didominasi oleh jenis kendaraan ringan (Light Duty Vehicle) yang mencapai hingga 177.577 kendaraan per hari. Menurut perhitungan emisi polutan NOx yang dilakukan oleh PPLH Universitas Sriwijaya (2013), besarnya estimasi emisi pada tahun 2010 mendekati nilai 3.138,46 ton/tahun, dimana jenis kendaraan berat (Heavy Duty Vehicle) sebagai kontributor utama yang mencapai hingga 180.476 kendaraan per hari dalam menghasilkan emisi NOx. Nilai total emisi NOx Kota Denpasar berdasarkan data Instansi Dinas Perhubungan (2012) dapat dikatakan sama dengan kondisi yang dialami oleh Kota Palembang pada tahun 2010. Tingginya nilai emisi NOx ini disebabkan karena besarnya mobilitas jenis kendaraan roda empat (mobil) di Kota Denpasar. Sementara dari penelitian inventarisasi gas rumah kaca yang dilakukan di Yogyakarta (2013), emisi GRK untuk polutan NOx mencapai18.13 Gg/tahun, yang berasal dari pembakaran bahan bakar di jalan (On Road) dengan menggunakan data tahun 2011.

Tingginya beban emisi polutan $\mathrm{NO}_{x}$ pada jenis jalan ini (jalan raya) disebabkan oleh beberapa hal 
yang perlu dianalisis lebih lanjut. Jenis aktivitas di jalan raya memiliki tingkat aktivitas lalu lintas tertinggi dengan total beban kendaraan mencapai 137.577 kendaraan per hari. Semakin banyak jumlah kendaraan yang beraktivitas pada tipe jalan tersebut maka akan berdampak linear pada jumlah emisi $\mathrm{NO}_{\mathrm{x}}$ yang ditimbulkan pula. Sebagai contoh jalan raya yang dapat dianalisis adalah Jalan Mahendradata dengan lebar badan jalan $8 \mathrm{~m}$ (Dinas Perhubungan, 2011), terlihat bahwa ada fenomena yang terjadi dimana secara logika ketika jalan tersebut memiliki lebar yang besar, maka kendaraan yang berlalu lintas tidak akan mengalami perlambatan. Ketika kendaraan yang beraktivitas tidak mengalami perlambatan maka pembakaran yang terjadi dalam mesin kendaraan tersebut tergolong pembakaran sempurna. Pembakaran sempurna akan menghasilkan emisi gas $\mathrm{NO}_{\mathrm{x}}$ semakin meningkat pula.

\subsection{Beban Emisi Sumber Bergerak Gas Polutan $\mathrm{SO}_{2}$ di Kota Denpasar}

Bahan bakar bensin mengandung unsur belerang $=\mathrm{S}$ (sulfur). Pada saat terjadi pembakaran, $\mathrm{S}$ akan bereaksi dengan $\mathrm{H}$ dan $\mathrm{O}$ untuk membentuk senyawa sulfat dan sulfur oksida. Di Kota Denpasar, besarnya nilai polutan $\mathrm{SO}_{2}$ tahun 2012 mencapai total 212,34 ton/tahun dan tingginya nilai estimasi emisi $\mathrm{SO}_{2}$ ini sebagian besar berasal dari sumber bergerak on road jalan rayadan didominasi oleh jenis kendaraan ringan (Light Duty Vehicle) yang mencapai angka hingga 137.577 kendaraan/hari.

Menurut perhitungan emisi polutan $\mathrm{SO}_{2}$ yang dilakukan oleh PPLH Universitas Sriwijaya (2013), besarnya estimasi emisi pada tahun 2010 mendekati nilai 210,42 ton/tahun, dimana jenis kendaraan berat (Heavy Duty Vehicle) sebagai kontributor utama dalam menghasilkan emisi $\mathrm{SO}_{2}$ yang mencapai angka 180.476 kendaraan per hari. Nilai total estimasi tahunan emisi $\mathrm{SO}_{2}$ antara Kota Denpasar dan Kota Palembang tidak jauh berbeda, salah satu penyebab perbedaan nilai emisi ini pada jenis kendaraan kontributor utama penghasil emisi $\mathrm{SO}_{2}$ yang memadati ruas jalan raya kota tersebut. Kota Denpasar yang merupakan daerah pariwisata menjadikan kota ini memiliki arus lalu lintas yang padat akan kendaraan pribadi yang mencapai hingga 187.059 kendaraan/tahun (Samsat, 2012). Sementara Kota Palembang yang merupakan kota dagang dan industri lebih banyak dipadati dengan jenis kendaraan berat hingga mencapai 57.412 kendaraan/ tahun (PPLH Universitas Sriwijaya, 2013).

\subsection{Beban Emisi Sumber Bergerak Gas Polutan HC di Kota Denpasar}

Bensin adalah senyawa hidrokarbon (HC), jadi setiap HC yang didapat di gas buang kendaraan menunjukkan adanya bensin yang tidak terbakar dan terbuang bersama sisa pembakaran. Sebagian besar emisi penguapan $\mathrm{HC}$ berasal dari aktivitas pengisian bahan bakar, kegiatan berkendara dan aktivitas di tempat parkir. Pada aktivitas pengisian bahan bakar di SPBU, evaporasi atau penguapan bahan bakar fosil akan mengasilkan emisi HC. Pada kegiatan berkendara, emisi HC (Hidro Karbon) dihasilkan dari proses pembakaran dalam ruang bakar mesin kendaraan yang dikeluarkan melalui pipa gas buang saat mesin baru dimatikan dan ketika mesin baru dinyalakan. Sedangkan pada tempat parkir, keadaan mesin diasumsikan dalam kondisi pendinginan sehingga gas yang diemisikan adalah gas yang mengalami penyerapan emisi panas (hot soak emission) yang terjadi setelah kendaraan digunakan.

Di Kota Denpasar, estimasi emisi HC mencapai hingga 20.049,87 ton/tahun yang sebagian besar berasal dari emisi jalan-jalan raya dan dihasilkan oleh jenis kendaraan sepeda motor (scooter) yang mencapai 406.679 kendaraan/hari. Hal ini didukung dengan data kendaraan dan motor dari Intansi Dinas Samsat bahwa total kendaraan roda dua di daerah Denpasar tahun 2012 mencapai hingga 1.213.271 kendaraan (Samsat, 2012). Jumlah kendaraan sepeda motor ini jauh lebih besar daripada kendaraan roda empat atau mobil yang hanya mencapai 544.321kendaraan di tahun 2010. Semakin tinggi nilai jumlah kendaraan maka emisi yang dihasilkan akan lebih besar pula.

Menurut perhitungan emisi polutan HCyang dilakukan oleh PPLH Universitas Sriwijaya (2013), besarnya estimasi emisi pada tahun 2010 mendekati nilai 10.209,29 ton/tahun, dimana jenis kendaraan sepeda motor sebagai kontributor utama dalam menghasilkan emisi $\mathrm{SO}_{2}$ yang mencapai hingga 9.231,15 kendaraan/hari. Nilai estimasi emisi HC yang dihasilkan Kota Denpasar jauh melewati Kota Palembang, hal ini disebabkan karena total kendaraan sepeda motor di Kota Denpasar 2 kali lipat lebih besar dibandingkan total kendaraan yang ada di Kota Palembang.

\subsection{Beban Emisi Sumber Bergerak Gas Polutan $\mathbf{P M}_{10}$ di Kota Denpasar}

Partikel adalah pencemar udara yang dapat berada bersama-sama dengan bahan atau bentuk pencemar lainnya. Partikulat terdiri dari unsur C (karbon) yang masih berupa butiran partikel, dan residu atau kotoran lain dihasilkan oleh pembakaran pada motor diesel. Partikulat sebagian besar dihasilkan oleh adanya residu dalam bahan bakar. Residu tersebut tidak ikut terbakar dalam ruang bakar, tetapi terbuang melalui pipa gas buang. Pembakaran mesin diesel paling banyak menghasilkan partikulat karena didalam bahan bakar diesel mengandung banyak residu dengan kadar $\mathrm{C}$ yang banyak. Hal itu mengakibatkan setelah selesai proses pembakaran, karbon/arang yang tidak terbakar akan terbuang melalui pipa gas buang. 
Di Kota Denpasar, estimasi emisi PM $_{10}$ mencapai hingga 444,16ton/tahun yang sebagian besar dihasilkan oleh sumber bergerak on road jalan raya, sebesar $98.42 \%$ dari jumlah total emisi tahunan $\mathrm{PM}_{10}$. Jenis kendaraan ringan (Light Duty Vehicle) merupakan kontributor tertinggi yang terdistibusi di jalan-jalan utama Kota Denpasar yang menyumbang emisi sebanyak 177.577 kendaraan/ hari. Untuk sumber bergerak on-road, emisi $\mathrm{PM}_{10}$ sangat dipengaruhi oleh tingkat kualitas bahan bakar yang digunakan oleh kendaraan bermotor. Kendaraan dengan mesin diesel melepas $\mathrm{PM}_{10}$ lebih banyak dibandingkan dengan kendaraan yang menggunakan bahan bakar bensin atau pertamax. Di Kota Denpasar, penghasil emisi PM $_{10}$ terbesar kedua setelah jenis kendaraan ringan adalah jenis kendaran berat. Jenis kendaraan dengan mesin diesel merupakan penghasil emisi $\mathrm{PM}_{10}$ yang banyak terkonsentrasi di sekitar terminal, area bongkar muat barang kargo serta beberapa ruas jalan raya yang banyak dilalui kendaraan berat. Kendaraan berat akan membutuhkan bahan bakar yang lebih banyak dan menghasilkan pembakaran yang lebih besar pula. Semakin besar pembakaran bahan bakar untuk menghasilkan daya yang besar, maka beban emisi hasil sisa pembakaran dalam mesin kendaraan akan semakin besar.

Menurut perhitungan emisi yang dilakukan oleh PPLH Universitas Sriwijaya (2013) dengan menggunakan data tahun 2010 nilai emisi $\mathrm{PM}_{10}$ mencapai nilai 305,16 ton/tahun, dimana jenis kendaraan ringan (mobil) sebagai kontributor utama dalam menghasilkan emisi $\mathrm{PM}_{10}$ yang mencapai hingga 167.252 kendaraan/hari. Berdasarkan data tersebut, diperoleh perbandingan bahwa emisi $\mathrm{PM}_{10}$ yang dihasilkan hampir sama baik di Kota Denpasar maupun di Kota Palembang. Mengingat bahwa total jumlah kendaraan ringan yang merupakan penghasil utama emisi $\mathrm{PM}_{10}$ pada dua Kota tersebut hampir sama.

Partikel yang berukuran $10 \mu \mathrm{m}\left(\mathrm{PM}_{10}\right)$ berdampak buruk bagi kesehatan maupun lingkungan. Apabila $\mathrm{PM}_{10}$ masuk ke dalam ke sistem pernapasanmanusia maka menyebabkan gangguan-gangguan pernapasan,seperti: iritasi, batuk-batuk dan kesulitan bernapas, mengakibatkan menurunnya fungsi paru-paru, memperparah penyakit asma, menimbulkan bronkhitis kronis, hingga menyebabkan kematian dini bagi penderita penyakit jantung dan paru-paru. Sementara itu, dampak $\mathrm{PM}_{10}$ bagi lingkungan adalah timbulnya kerusakan lingkungan akibat mengendapnya partikel yang mengandung asam pada perairan-perairan, tanah serta hutan serta dapat menimbulkan kerusakan bangunan atau monumen yang akan mengganggu keindahan karena beberapa partikel yang mengandung asam mampu menghancurkan beberapa jenis material (Kementrian Lingkungan Hidup, 2013).

\subsection{Beban Emisi Sumber Bergerak Gas Polutan $\mathrm{CO}_{2}$ di Kota Denpasar}

Sisa hasil pembakaran bahan bakar minyak yang digunakan oleh kendaraan bermotor adalah sumber utama dari emisi $\mathrm{CO}_{2}$ di Kota Denpasar yang terkonsentrasi di jalan-jalan utama dengan tingkat mobilitas yang sangat tinggi. Hal ini dibuktikan dari hasil penelitian seperti yang terlihat pada Tabel 5 bahwa total $\mathrm{CO}_{2}$ di Kota Denpasar mencapai nilai 984.280,21 ton/tahun, yang sebagian besar berasal dari emisi sumber bergerak di jalan raya dan dihasilkan oleh kendaraan ringan (Light Duty Vehicle) yang mencapai $62 \%$ dari total emisi $\mathrm{CO}_{2}$. Menurut perhitungan emisi yang dilakukan oleh PPLH Universitas Sriwijaya (2013) dengan menggunakan data tahun 2010 nilai emisi $\mathrm{CO}_{2}$ mencapai nilai 548.854,83 ton/tahun, dimana jenis kendaraan ringan (mobil) sebagai kontributor utama dalam menghasilkan emisi $\mathrm{CO}_{2}$. Sedangkan menurut penelitian gas rumah kaca yang berasal dari sektor transportasi yang dilakukan di Kota Yogyakarta dengan menggunakan data inventarisasi tahun 2010, emisi gas $\mathrm{CO}_{2}$ mencapai $1.246,92 \mathrm{Gg} /$ tahun yang sebagian besar dihasilkan dari jenis kendaraan sepeda motor (inventarisasi emisi gas rumah kaca D.I. Yogyakarta, 2013). Dari perhitungan emisi gas $\mathrm{CO}_{2}$ yang dilakukan dari ketiga kota besar tersebut, emisi gas $\mathrm{CO}_{2}$ yang dihasilkan Kota Denpasar jauh lebih kecil daripada emisi yang dihasilkan di Kota Yogyakarta, hal ini dapat dibuktikan dari jumlah kendaraan ringan di Kota Denpasar lebih kecil hingga mencapai 177.577 kendaraan (Samsat, 2012). Sementara pada tahun 2010 di Kota Yogyakarta, jumlah kendaraan sepeda motor mencapai 1.488.033kendaraan(inventarisasi emisi gas rumah kaca D.I. Yogyakarta, 2013).

Tingginya nilai $\mathrm{CO}_{2}$ diakibatkan karena arus lalu lintas padat sehingga menyebabkan kemacetan lalu lintas.Dalam kondisi lalu lintas macet, pembakaran bahan bakar (bensin, solar) pada mesin kendaraan bermotor tetap berlangsung mengeluarkan emisi (A. Tresna Sastrawijaya). Pembakaran bensin maupun solar akan lebih efisien jika mobil atau motor dilarikan dengan kecepatan yang konstan, dan mengurangi frekuensi pengereman dan menstarter. Sebaliknya dalam kondisi jalanan macet maka pembakaran bahan bakar kendaraan bermotor tidak akan efisien lagi dan tidak sempurna, pada saat itu yang terjadi adanya pengumpulan senyawa-senyawa yang dikeluarkan oleh kendaraan bermotor pada satu tempat.

\subsection{Beban Emisi Sumber Bergerak Gas Polutan CO di Kota Denpasar}

Karbon monoksida (CO) merupakan suatu gas yang tidak berwarna, tidak berbau, dan tidak berasa. Keberadaan gas ini sebagian besar merupakan hasil pembakaran bahan bakar fosil dengan udara, berupa gas buangan. Bila karbon didalam bahan bakar 
terbakar dengan sempurna, akan terjadi reaksi yang menghasilkan $\mathrm{CO}_{2}$ tetapi apabila unsur oksigen udara tidak cukup, akan terjadi pembakaran tidak sempurna yang menghasilkan gas CO. Sisa hasil pembakaran bahan bakar minyak yang digunakan oleh kendaraan bermotor adalah sumber utama dari emisi CO di Kota Denpasar yang terkonsentrasi di jalan-jalan utama dengan tingkat mobilitas yang sangat tinggi.

Terminal Ubung memberikan kontribusi beban emisi polutan gas CO terbesar apabila dibandingkan dengan ketiga terminal lainnya, yaitu: Terminal Kargo, Terminal Kreneng, dan Terminal Tegal. Hal ini disebabkan karena Terminal Ubung merupakan terminal aktif yang banyak menampung bus kecil, bus besar, dan angkot dimana mesin kendaraan dalam posisi idling (kendaraan berhenti namun mesin tetap menyala) untuk menunggu penumpang. Ketika mesin dalam keadaan idling, polutan yang banyak dihasilkan oleh bus kecil, bus besar yang menggunakan bahan bakar solar yaitu polutan CO. Berdasarkan dari Tabel 6.1 dan merujuk pada Tabel 5.4 bahwa, total emisi gas CO di Kota Denpasar mencapai 55.432,04 ton/tahun yang sebagian besar berasal dari emisi sumber bergerak di jalan raya dan dihasilkan oleh kendaraan roda dua atau sepeda motor. Tingginya nilai emisi $\mathrm{CO}$ pada ruas-ruas jalan raya ini dapat diakibatkan dari tingginya kepadatan lalu lintas yang menyebabkan kemacetan maka tingkat emisi karbon monoksida yang dihasilkan semakin meningkat, karena menurut Zhai, H., et.al, (2008) diketahui bahwa emisi CO meningkat seiring dengan menurunnya kecepatan.

Menurut perhitungan emisi yang dilakukan oleh PPLH Universitas Sriwijaya (2013) dengan menggunakan data tahun 2010 nilai emisi COmencapai nilai 22.685,92ton/tahun, dimana jenis kendaraan roda duaatau sepeda motor sebagai kontributor utama dalam menghasilkan emisi $\mathrm{PM}_{10}$. Hal ini didukung oleh data jumlah kendaraan dari intansi Samsat bahwa total kendaraan roda dua yang ada di Bali mencapai 1.213.271 kendaraan di tahun 2012. Sementara di Kota Palembang total kendaraan roda dua mencapai 544.321 kendaraan di tahun 2010. Tingginya kepemilikan kendaraan roda dua memberikan kontribusi yang besar terhadap mobilitas aktivitas kendaraan di jalan raya dan juga menghasilkan beban emisi yang besar pula.

$\mathrm{CO}$ tergolong gas yang beracun dan mematikan. Gas yang tidak menyebabkan iritasi ini memasuki tubuhmelalui pernapasan dan kemudian diserap ke dalam peredaran darah. Gas ini juga mampu mengikathemoglobin yang berfungsi untuk mengangkut oksigen dalam darah dengan daya ikat 240 kali lebih besardibandingkan dengan daya ikat antara hemoglobin dan oksigen, sehingga menyebabkan berkurangnyakapasitas darah dalam mengangkut oksigen. Secara langsung kompetisi ini akan menyebabkan pasokanoksigen ke seluruh tubuh menurun, sehingga melemahkan kontraksi jantung dan menurunkan volumedarah yang didistribusikan. Hal ini kemudian akan mempengaruhi fungsi organ-organ tubuh seperti otak, hati, pusat saraf dan janin.Sementara itu, tidak ditemukan laporan mengenai dampak langsung CO terhadap ekosistem. Secara tidak langsung $\mathrm{CO}$ dapat mendorong percepatan produksi nitrogen dioksida $\left(\mathrm{NO}_{2}\right)$ pada rantai reaksi yang menghasilkan ozon di udara ambien (di troposfer) yang merupakan pencemar sekunder yang dapat menimbulkan dampak terhadap tumbuh-tumbuhan. Tetapi peran CO di dalam rantai reaksi yang kompleks tersebut tidak terlalu dominan dibandingkan dengan senyawasenyawa hidrokarbon (Kementrian Lingkungan Hidup, 2013).

\subsection{Distribusi Sebaran Beban Emisi Polutan $\mathrm{NO}_{\mathrm{x}}, \mathrm{SO}_{2}, \mathrm{HC}, \mathrm{PM}_{10} \mathrm{CO}_{2}$ dan CO Sumber Bergerak (On Road) Kota Denpasar}

Kota Denpasar yang merupakan lokasi atau objek inventarisasi emisi terdiri dari 4 Kecamatan, yaitu: Kecamatan Denpasar Barat, Denpasar Utara, Denpasar Timur dan Denpasar Selatan. Untuk mengetahui pola sebaran dari emisi di Kota denpasar ini, maka untuk dikaji berdasarkan administratif atau berdasarkan Kecamatan. Nilai total beban emisi dipetakan dengan menggunakan GIS. Peta spasial untuk setiap sumber pencemar dibuat dengan memadukan data dalam excel dan GIS sehingga pada setiap selnya mengandung informasi nilai beban emisi dari sumber emisi $\mathrm{NO}_{\mathrm{x}}, \mathrm{SO}_{\mathrm{x}}, \mathrm{HC}, \mathrm{PM}, \mathrm{CO}$ dan $\mathrm{CO}_{2}$ dari semua sumberuntuk berbagai jenis kegiatan lalu lintas kendaraan di jalan raya, jalan kecil, terminal maupun dilapangan parkir.

Gambar 2 (a-f) memperlihatkan bahwa sebagian besar emisi polutan $\mathrm{NO}_{\mathrm{x}}, \mathrm{SO}_{2}, \mathrm{HC}, \mathrm{PM}_{10} \mathrm{CO}_{2}$ dan CO terdistribusi di Kecamatan Denpasar Barat, hal ini dapat dianalisis lebih jauh karena letak Kecamatan Denpasar Barat yang dekat dengan Kuta yang merupakan pusat pariwisata menjadikan ruas jalan tersebut selalu ramai dan padat dengan kendaraan, terutama kendaraan ringan (Light Duty Vehicle). Selain itu banyaknya persimpangan pada ruas jalan raya ini menyebabkan emisi yang dihasilkan juga akan semakin meningkat. Hal ini berdasarkan hasil survei yang dilakukan oleh Zahra (2009) bahwa beban emisi yang dihasilkan ketika idling time yang disebabkan persimpangan yang macet akan memerlukan konsumsi bajan bakar yang lebih besar pula dibandingkan ketika kendaraan dalam kondisi running. Sehingga emisi yang dihasilkan akan lebih besar pula. Sedangkan pada Kecamatan Denpasar Utara, kontributor utama penghasil emisi NO adalah kendaraan berat (Heavy Duty Vehicle) yang banyak melewati ruas jalan besar seperti: Gatot Subroto dan Cokroaminoto.Kendaraan berat akan memerlukan konsumsi bahan bakar yang besar, semakin besar nilai konsumsi bahan bakar 
Tabel 6. Prediksi Total Beban Emisi Kota Denpasar

\begin{tabular}{lcccccc}
\hline Tahun Prediksi & $\begin{array}{c}\text { NOx Total } \\
\text { (ton/thn) }\end{array}$ & $\begin{array}{c}\mathrm{SO}_{2} \text { Total } \\
\text { (ton/Thn) }\end{array}$ & $\begin{array}{l}\text { HC Total } \\
\text { (ton/thn) }\end{array}$ & $\begin{array}{c}\mathrm{PM}_{10} \text { Total } \\
\text { (ton/thn) }\end{array}$ & $\begin{array}{c}\mathrm{CO}_{2} \text { Total } \\
\text { (ton/thn) }\end{array}$ & $\begin{array}{c}\text { CO Total } \\
\text { (ton/thn) }\end{array}$ \\
\hline Tahun 2013 & $3.765,89$ & 212,34 & $20.049,87$ & 444,16 & $984.280,21$ & $55.432,04$ \\
Tahun2014 & $4.029,50$ & 227,20 & $21.453,36$ & 475,25 & $1.053 .179,82$ & $59.312,28$ \\
Tahun 2015 & $4.311,57$ & 243,11 & $22.955,10$ & 508,52 & $1.126 .902,41$ & $63.464,14$ \\
Tahun 2016 & $4.613,38$ & 260,13 & $24.561,95$ & 544,12 & $1.205 .785,58$ & $67.906,63$ \\
Tahun2017 & $4.936,31$ & 278,33 & $26.281,29$ & 582,20 & $1.290 .190,57$ & $72.660,10$ \\
Tahun2018 & $5.281,86$ & 297,82 & $28.120,98$ & 622,96 & $1.380 .503,91$ & $77.746,30$ \\
Tahun2019 & $5.651,59$ & 318,67 & $30.089,45$ & 666,56 & $1.477 .139,19$ & $83.188,54$ \\
Tahun2020 & $6.047,20$ & 340,97 & $32.195,71$ & 713,22 & $1.580 .538,93$ & $89.011,74$ \\
\hline
\end{tabular}

maka emisi yang dihasilkan juga akan semakin meningkat. Untuk kawasan Denpasar Timur, tingginya emisi $\mathrm{NO}_{\mathrm{x}}$ yang dihasilkan karena daerah ini merupakan wilayah padat kantor pemerintahan dan terletak di pusat Kota Denpasar sehingga aktivitas masyarakat cenderung terpusat dikawasan tersebut menyebabkan arus lalu lintas menjadi besar sehingga volume kendaraan menjadi tinggi. Sementara pada kawasan Denpasar Selatan, padatnya arus lalu lintas dominan terjadi di sekitaran Jalan Pantai Sindu karena pantai ini merupakan tujuan salah satu destinasi pariwisata yang ramai dikunjungi. Tetapi distribusi sebaran emisi NOx di kawasan Kecamatan Denpasar Selatan tidak sebesar emisi pada 3 kecamatan lainnya. Hal ini dikarenakan Kecamatan Denpasar Selatan lebih sedikit memiliki ruas jalan utama penghubung dan jauh dari pusat perkantoran kota.

Selain bermanfaat untuk mengukur beban pencemaran udara dan pemetaan distribusi beban emisi, inventarisasi emisi juga bermanfaat untuk menyajikan prediksi total beban emisi pada beberapa tahun mendatang. Berdasarkan Gambar 2.2 dan data dari Dinas Biro Pusat Statistik (2008), jumlah kendaraan bermotor dari tahun ke tahun jumlahnya terus meningkat dimana pada tahun 2003 jumlah kendaraan bermotor di Kota Denpasar berjumlah 345.332 unit dan terus mengalami peningkatan dari tahun ke tahun sampai tahun 2007 sebesar 481.086 unit dengan kenaikan rata-rata sebesar 7\% tiap tahunnya. Dari data BPS (2008) dan dari hasil perhitungan beban emisi Kota Denpasar berdasarkan basis data tahun 2013, maka dapat diprediksi total beban emisi yang akan dialami Kota Denpasar seperti pada Tabel 6 .

Berdasarkan Tabel 6, prediksi emisi $\mathrm{CO}_{2}$ di Kota Denpasar pada tahun 2020 mencapai nilai 1.580.538,93 ton/tahun. Kontribusi gas $\mathrm{CO}_{2}$ Kota Denpasar lebih banyak dihasilkan oleh jenis kendaraan ringan (Light Duty Vehicle). Nilai emisi $\mathrm{CO}_{2}$ tertinggi terletak di Kecamatan Denpasar Barat yaitu pada ruas-ruas jalan: Mahendradata, Teuku Umar, Buana Raya, dan Gunung Soputan serta di Kecamatan Denpasar Timur meliputi ruas jalan sekitaran Niti Mandala Renon. Hal ini dapat dianalisis sebagai berikut: emisi $\mathrm{CO}_{2}$ terjadi ketika di dalam mesin terjadi pembakaran sempurna, pembakaran sempurna terjadi ketika kendaraan berada dalam kondisi running. Kendaraan dapat melaju dengan kecepatan tinggi untuk melakukan pembakaran apabila tidak terjadi kemacetan lalu lintas di jalan raya, maka emisi $\mathrm{CO}_{2}$ lebih banyak terjadi pada ruas jalan raya besar.

Tingginya nilai prediksi emisi di tahun 2020 dari sektor transportasi akan berdampak langsung pada peningkatan emisi Gas Rumah Kaca (GRK) yang menyababkan perubahan iklim global dan peningkatan suhu bumi diikuti dengan meningkatnya permukaan air laut akibat pencairan es di wilayah kutub. Dampak peningkatan konsentrasi GRK akan mengakibatkan beberapa keadaan yang merugikan, seperti: bencana banjir, kekeringan, meningkatnya penyakit tropis (malaria dan demam berdarah).

\section{SIMPULAN DAN SARAN}

\subsection{Simpulan}

Berdasarkan analisis dan pembahasan sebelumnya, maka dapat disimpulkan beberapa hal sebagai berikut:

a. Total besar beban emisi berdasarkan sumber bergerak di jalan (On Road) di Kota Denpasar untuk masing-masing gas pencemar $\mathrm{NO}_{\mathrm{x}}$ adalah 3.765,89 ton/tahun, $\mathrm{SO}_{2}$ adalah 212,34 ton/tahun, $\mathrm{HC}$ adalah $20.049,87$ ton/tahun, $\mathrm{PM}_{10}$ adalah 444,16 ton/tahun, $\mathrm{CO}_{2}$ adalah $984.280,21$ ton/ tahun, dan CO adalah 55.432,04 ton/tahun. Secara keseluruhan, nilai total beban emisi gas pencemar Kota Denpasar bernilai lebih besar dibandingkan dengan total beban emisi gas pencemar di Kota Palembang.

b. Sebaran beban emisi masing-masing gas pencemar $\mathrm{NO}_{\mathrm{x}}$ dan $\mathrm{CO}_{2}$ dengan nilai tertinggi 115-239 ton/tahun dan 26.944-4.735 ton/tahun lebih banyak terdistribusi pada Kecamatan Denpasar Barat dan kawasan Niti Mandala Renon. Sebaran beban emisi gas pencemar $\mathrm{SO}_{2}$ dengan nilai tertinggi 15,5-44 ton/tahun lebih 
banyak terdistribusi pada Kecamatan Denpasar Barat. Sebaran beban emisi gas pencemar HC dengan nilai tertinggi 471-954 ton/tahun lebih banyak terdistribusi pada Kecamatan Denpasar Barat dan kawasan Niti Mandala Renon. Sebaran beban emisi gas pencemar $\mathrm{PM}_{10}$ dengan nilai tertinggi 11,5-21 ton/tahun lebih banyak terdistribusi pada Kecamatan Denpasar Barat, kawasan Pasar Badung, kawasan Lapangan Puputan dan kawasan Niti Mandala Renon.Sebaran beban emisi gas pencemar CO tertinggi 1.277-1.912 ton/tahun lebih banyak terdistribusi pada Kecamatan Denpasar Barat, kawasan Pasar Badung, kawasan Lapangan Puputan, kawasan Niti Mandala Renon dan kawasan Universitas Udayana.

\subsection{Saran}

a. Perlu dilakukan suatu upaya untuk mengurangi kuantitas sepeda motor digantikan dengan kendaraan yang memuat penumpang lebih banyak terangkut sehingga pemakaian sepeda motor berkurang.

b. Perlu diberlakukan pemeriksaan efisiensi proses pembakaran kendaraan bermotor secara berkala sebagai upaya pencegahan emisi yang lebih besar.

c. Sebaiknya perlu diadakan penelitian lebih lanjut mengenai pengaruh aspek lingkungan dan kebijakan pemerintah dalam mengatasi emisi $\mathrm{NO}_{\mathrm{x}}, \mathrm{SO}_{2}, \mathrm{HC}, \mathrm{PM}_{10}, \mathrm{CO}_{2}$, dan $\mathrm{CO}$ yang semakin meningkat, sehingga dapat merubah pola hidup masyarakat.

\section{DAFTAR PUSTAKA}

EMEP/EEA air pollutant emission inventory guidebook. 2009. Technical Guidance to Prepare National Emission Inventories.European Environment Agency: Luxembourg
Emission Inventoryfor the City of PalembangSouth Sumatra-Indonesia. 2013. Under the Project"Clean Air for Smaller Cities in the ASEAN Region". Environmental Study Center : University of Sriwijaya.

IPCC. 2006. Guidelines for National Greenhouse Gas Inventories, Prepared by the National Greenhouse Gas Inventories Programme. Eggleston H.S., Buendia L., Miwa K., Ngara T. and Tanabe K. (eds). Published: IGES, Japan.Biro Pusat Statistik, 2010. Draf Denpasar dalam Angka 2010. Denpasar.

Kementerian Lingkungan Hidup, 2013.Buku I : Pedoman Umum Penyelenggaraan Inventarisasi Gas Rumah Kaca Nasional.

Pemerintah Daerah Istimewa Yogyakarta. 2013. Inventarisasi Emisi Gas Rumah Kaca Daerah Istimewa Yogyakarta Tahun 2011.

PPLH. 2013. Emission Inventory: Under the Project Clean Air for Smaller Cities in the ASEAN Region. Sumatera Selatan: Universitas Sriwijaya.

U.S.EPA. 2005. Emission Inventory Improvement Program: Preferred and Alternative Methods For Gathering And Locating Specific Emission Inventory Data. Washington, DC: U.S.EPA.

Zahra, E dan Driejana. 2009. Perbandingan Estimasi Beban Emisi CO Dan $\mathrm{CO}_{2}$ Dengan Pendekatan Konsumsi Bahan Bakar dan Kecepatan Kendaraan (studi kasus : bunderan cibiru-lembang). Bandung: Institusi Teknologi Bandung.

Zhai, H., H. Christopher and F., Nagui M. R. 2008. Speed and Facility Specific Emissions Estimates for Transit Buses based on Measured Speed Profiles. North Carolina State University. 